\section{New science pressure group}

Tokyo

IN an unusual move, a powerful pressure group has been formed within Japan's ruling Liberal Democratic Party (LDP) to push for dramatic increases in government spending on research.

The pressure group, called the "special committee to reinforce maintenance of the basic research base and international research cooperation activity', is chaired by Kishiro Nakamura, a former head of the Science and Technology Agency, and includes a broad range of LDP politicians with strong links to the key science-related ministries and agencies, as well as to the all-powerful Ministry of Finance. Among them are two former ministers of education, Takeo Nishioka and Kosuke Hori, and several 'old boys' from the Ministry of International Trade and Industry (MITI), including the committee secretary, Hitoshi Murai, who used to be deputy director of MITI's Agency of Industrial Science and Technology and is now a vice minister of the Ministry of Finance.

Similar committees have been formed in the past to promote, for example, development of space and energy and overseas development assistance (ODA), but this is the first time such a broad-based political group has been formed to back science. As one government official says, "science and technology policy has tended to be neglected by politicians because there is no money or votes in it." Another, from MITI, describes the formation of the committee as "epoch-making".

A number of factors have conspired to create the right environment for formation of the group. Conditions in Japan's rundown national universities have reached a state of crisis, and powerful academics in particular, Akito Arima, president of Tokyo University - have been calling for a massive injection of funds to rebuild, reequip and re-staff the universities. Earlier this year, the Minister of Education, Science and Culture, LDP politician Yutaka Inuoe, visited Tokyo University to see what all the fuss was about and ended up apologizing to Arima for the appalling state of affairs he found.

But it is not just academics who are voicing their concern. Leaders in industry - in particular, the powerful Federation of Economic Organization (Keidanren) - are worried that Japan will soon run short of researchers to drive Japan's growing high-technology industry. In October, Gaishi Hiraiwa, chairman of Keidanren, sent a remarkably frank letter to Jiro Kondo, president of the Science Council of Japan, expressing the federation's concern about the government research system. In the letter, he says that the deteriorating research and education environ- ment in Japan's universities and national laboratories is causing young people to turn their backs on science and engineering. Japan's goal of building a country based on science and technology is "collapsing at the foundaions", the letter concludes. Keidanren calls on the government to double its spending on research to 1 per cent of gross national product (GNP) over the next five years to attract young people back to science.

A third factor is the emergence of 'big science' on the international political scene. Each time the Japanese prime minister meets with President George Bush, he is asked for a contribution to the US Superconducting Super Collider. Problems with the global environment have also helped to make science an international political issue.

The new LDP committee held its first hearing on 6 November with a presentation from Keidanren. This was followed on 12 November with a hearing from Akito Arima and Jun-ichi Nishizawa, president of Tohoku University. On 19 November, six young government researchers explained to the committee the problems they face in Japan's fund-starved government research laboratories. And last week (26 November) it was the turn of representatives of private universities.

Next on the committee's agenda is a hearing early this month on a soon-to-bereleased report from the influential Council for Promotion of Administrative Reform. The council, which is composed of

\section{Moscow}

SOVIET intellectual life has virtually collapsed as a result of the political disintegration of the Soviet Union and the efforts to switch the economy to market principles at a time of galloping inflation and shortages.

On 20 November, the financing of nearly 80 government ministries and other central bodies was stopped. The central government and the republics have agreed to preserve - in modified form - the foreign ministry and the ministries of the interior, of culture, of railways and of power engineering as well as the independent atomic energy organization and the customs administration.

Many institutions of higher education and industrial research are so short of money that they are having to suspend research programmes and reduce personnel. As a result of the economic crisis and the severance of economic ties, industrial enterprises have no interest in financing projects that do not produce quick returns. top industrialists and academics, is a powerful advisory body to the prime minister. It has two committees, one of which, headed by Kazuo Inamori, president of Kyocera Corporation, and called the ' $\mathrm{Ja}$ pan within the World' committee, is charged with looking at ODA, the influx of foreign workers to Japan, the global environment problem, and, in another sign of the growing political importance of science, the internationalization of academic research.

The Inamori committee, like Keidanren, is keen to recommend that the government should double its spending on research to 1 per cent of GNP. The Ministry of Finance is opposed to such a recommendation, and there is a heated debate on the final contents of the report. Whatever the outcome, the Inamori report will provide powerful ammunition for the LDP committee. And later this month a committee of the Council of Science and Technology, Japan's top science policy-making body, will also release recommendations for the next five to ten years which are expected to focus attention on problems in the government research sector (Nature 350, 544; 18 April 1991).

Armed with all of these reports, the LDP committee will push for removal of the strict ceilings on government spending on research, which have been in place for years. Government officials say the committee will probably make a move early next summer in combination with MITI, the Science and Technology Agency and the Ministry of Education, Science and Culture in time for fiscal 1993 budget requests.

David Swinbanks

\title{
Exodus likely to increase
}

The country's largest research institute of metal-cutting lathes, for example, has an order-book for next year only 15 per cent of normal, and has to cut its staff, according to Pavel Solovyov, the institute's deputy directory responsible for research projects.

Moscow State University, which has more than 8,000 professors, instructors and research fellows, almost 5,000 postgraduates and 25,000 students, is on the brink of financial collapse. On 20 November, the staff decided to ask the Russian government to take over the university as an autonomous and self-governing institution. But Viktor Sadovnicy, the prorector, said that even then, "we shall need international help."

In an appeal to Boris Yeltsin, the Russian president, Moscow students warned that they would stage protest rallies if the Russian government did not take steps to improve social guarantees for students and raise stipends. Many other institutions of higher education had to borrow money 